\title{
Trophic roles of heterotrophic nanoflagellates and ciliates among planktonic organisms in a hypereutrophic pond
}

\author{
Shin-ichi Nakano*, Nobuyoshi Ishii, Pathmalal M. Manage, Zen'ichiro Kawabata \\ Department of Environmental Conservation, Ehime University, Tarumi 3-5-7, Matsuyama 790-8566, Ehime, Japan
}

\begin{abstract}
We followed seasonal changes in abundance of bacteria, heterotrophic nanoflagellates (HNF), ciliates and crustaceans, and consumption of bacteria by the protozoans, to investigate trophic interactions among these organisms in a hypereutrophic pond from March to October 1997. Densities of HNF and ciliates were high and attained a maximum of $1.4 \times 10^{5}$ and $3500 \mathrm{cells} \mathrm{ml}^{-1}$, respectively. However, the high densities decreased as chlorophyll concentration increased. Since the predominant phytoplankton species was Microcystis aeruginosa (Cyanophyceae), toxin produced by the alga possibly affected growth of protozoans. Not only HNF but also ciliates were important consumers of bacteria, and consumption of bacteria by ciliates varied at the same level as that of HNF from August to October. Bacterial turnover rate $\left(\% \mathrm{~d}^{-1}\right)$ due to consumption by the protozoa ranged between 5.6 and 112 (mean 25), and there were significant relationships between densities of bacteria and specific ingestion rates (bacteria protozoan $\mathrm{cell}^{-1} \mathrm{~h}^{-1}$ ) of the protozoans. These results suggest that the food linkage between bacteria and the protozoans is substantial in the pond. We could not find any significant trophic relationships between HNF and ciliates, and between the protozoans and crustaceans.
\end{abstract}

KEY WORDS: Bacteria $\cdot$ Heterotrophic nanoflagellates $\cdot$ Ciliates $\cdot$ Microbial food web $\cdot$ Hypereutrophic pond

\section{INTRODUCTION}

It is well known that heterotrophic nanoflagellates (HNF) serve as important bacterial consumers in lakes (Nagata 1988, Bloem \& Bär-Gilissen 1989, Sanders et al. 1989), while consumption of bacteria by ciliates temporarily dominates among all heterotrophic links in a system (Śimek et al. 1990, 1995, 1998, Šimek \& Straskrabova 1992). Thus, there may be competition between HNF and ciliates for bacterial food, but the partitioning of bacterial food between HNF and ciliates is still poorly understood.

Although a great abundance of the genus Daphnia sometimes makes the microbial loop less important (Pace \& Funke 1991, Nakano et al. 1998), HNF (Sanders \& Porter 1990, Carrick et al. 1991, Jürgens

•E-mail: shin@agr.ehime-u.ac.jp
1994, Sanders et al. 1994) and ciliates (Tezuka 1974, Carrick et al. 1991, Sanders et al. 1994) are also considered to be important links in the transfer of bacterial biomass to metazoan zooplankton. Since HNF (Nakano 1994) and ciliates (Stoecker \& Capuzzo 1990) are rich in nitrogen and phosphorus, as are bacteria (Nagata 1986, Vadstein et al. 1988), they can be qualitatively good food for their predators. Previous studies have demonstrated efficient predation on HNF by oligotrichous ciliates (Jürgens et al. 1996), high predation pressure on HNF by rotifers (Dolan \& Gallegos 1991, Sanders et al. 1994) and on ciliates by copepods (Burns \& Gilbert 1993, Dobberfuhl et al. 1997). However, further studies on consumption of protozoa are needed to verify the role of the microbial loop in an aquatic ecosystem.

Predation on protozoa may have some effect on the consumption of bacteria by those protozoa, and the presence of cascading trophic interactions among bac- 
teria, protozoa and metazoan zooplankton has been pointed out. For example, Dolan \& Gallegos (1991) reported that the rotifer Synchaeta reduced consumption of bacteria by HNF through its predation on the HNF. Conversely, Pace \& Funke (1991) have reported that such cascading trophic interactions among bacteria, HNF, ciliates and Daphnia were not found in 2 temperate lakes. Although some studies have reported trophic interactions among bacteria, HNF and ciliates (Berninger et al. 1993, Stensdotter-Blomberg 1998), information about the microbial interactions is still limited.

In the present study, we focused on the food linkage among bacteria, HNF and ciliates and followed seasonal changes in abundance of these microorganisms and the consumption of bacteria by the protozoans in a hypereutrophic pond, to examine the trophic interactions among the microorganisms. In addition, we also followed the seasonal abundance of crustaceans to see interactions between microbial and classical food chains.

\section{MATERIALS AND METHODS}

Furuike Pond (altitude $40 \mathrm{~m}$ ) is an impoundment located in Sancho, Matsuyama City, Ehime Prefecture, Japan (Fig. 1). It has a surface area of ca $7400 \mathrm{~m}^{2}$, and its depth was $0.88 \pm 0.15 \mathrm{~m}$ (mean $\pm \mathrm{SD}$ ) during the study period. The pond is hypereutrophic, due to anthropogenic loading from the watershed. Field observations with 5 drifting buoys showed that there is a horizontal, clockwise eddy which mixes pelagic and near-shore waters. The eddy is caused by a sea breeze even if the wind is weak and thus its presence was probably continuous during the study period.

Water samples for determination of abundance of organisms were collected twice a month, from the surface with an 81 bucket, at a near-shore station (Fig. 1) from March to October 1997. To determine consumption of bacteria by protozoa, grazing experiments were also conducted at the same intervals over the same period. All samples were taken at around the same time of the day (09:30 to 10:30 h). Water temperature was measured with a thermistor (TOA Electronics Co. Ltd). To measure chlorophyll a concentration a measured portion of each water sample was filtered through a Nuclepore filter with pore size of $0.2 \mu \mathrm{m}$ to retain seston. The filter was then placed into a glass test tube and $6 \mathrm{ml}$ of $\mathrm{N}, \mathrm{N}$-dimethylformamide (DMF) was added to extract chlorophyll a. The amount of chlorophyll a thus extracted. was determined by the fluorometric method (Rami \& Porath 1980).

Immediately after collection, two $50 \mathrm{ml}$ portions of the water sample were fixed, one with glutaraldehyde

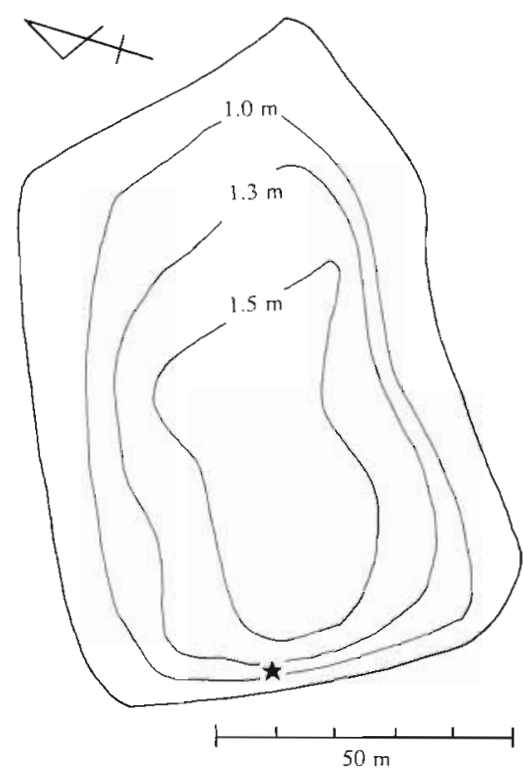

Fig. 1. Map of Furuike Pond (Matsuyama City, Ehime Prefecture, Japan) showing the sampling site

to a final concentration of $1 \%$ for enumeration of bacteria and heterotrophic nanoflagellates (HNF), and the other with acidified Lugol's solution to a final concentration of $1 \%$ for enumeration of ciliates. Bacteria were counted using the fluorescent dye diamidinophenylindole (DAPI), direct count method (Porter \& Feig 1980) with an epifluorescence microscope. HNF were enumerated under ultraviolet excitation using the primulin staining method (Caron 1983). We counted nanoflagellates as HNF if they showed no obvious red chlorophyll fluorescence under green excitation. Since the cell shapes of some ciliate species may change due to fixation, an unfixed portion of the water sample was brought to our laboratory, and the dominant ciliate species were identified under a microscope within $2 \mathrm{~h}$ of collection using the classification guides of Mizuno \& Takahashi (1991) and Patterson \& Hedley (1992). We used $10 \%$ methylcellulose $(15 \mathrm{cp})$ solution to slow down swimming ciliates. The ciliate sample fixed with acid Lugol's solution was concentrated by natural sedimentation, and ciliate cells were enumerated for each species in a haematocytometer under a microscope.

For counting crustacean zooplankton, a measured volume of between 10 and 20 I of water was filtered through an approximately $200 \mu \mathrm{m}$ mesh (NXX 7) plankton net to concentrate the zooplankton, which were then fixed with acid Lugol's solution at a final concentration of $1 \%$. The fixed samples were concentrated by natural sedimentation for more than $24 \mathrm{~h}$ before a 0.2 to $1 \mathrm{ml}$ aliquot of the concentrated sample was put on a scaled glass slide, and all the 
zooplankters found there were counted at least twice.

Grazing rates of HNF and ciliates feeding on bacteria were determined with fluorescently labeled bacteria (FLB) (Sherr et al. 1987) obtained from a minicellproducing mutant strain of Escherichia coli. After cultivation of the bacterium in a liquid medium, minicells were separated using the method of Christen et al. (1983) and stained with the fluorescent dye 5- $(4,6-$ dichlorotriazin-2-yl) aminofluorescein (DTAF) following Sherr et al. (1987). FLB thus prepared are spherical with a diameter of 0.5 to $1 \mu \mathrm{m}$, and the size range overlaps that of in situ bacteria in Furuike Pond (Nakano \& Kawabata unpubl.).

$100 \mathrm{ml}$ portions of the water samples were poured into triplicate polycarbonate bottles. FLB were added to the bottles at between 1.0 and $1.5 \times 10^{6}$ cells $\mathrm{ml}^{-1}$. These densities represented between 2.0 and $9.5 \%$ of the in situ bacterial densities, being appropriate surrogate densities (McManus \& Okubo 1991). The FLBspiked water samples were incubated at in situ temperature. After 8 min of incubation, subsamples were fixed with $4 \%$ ice-cold, buffered glutaraldehyde, which is an effective fixative to reduce the egestion of bacteria ingested into a food vacuole of HNF and ciliates (Sanders et al. 1989). HNF and ciliates thus fixed were respectively retained on $0.8 \mu \mathrm{m}$ and $5 \mu \mathrm{m}$ black Nuclepore filters and stained with primulin as mentioned before, and FLB in the food vacuoles of protozoa were counted under an epifluorescence microscope. Protozoa were detected under ultraviolet excitation, and FLB in their food vacuoles were observed after switching to blue excitation. At least 100 cells of HNF and 20 to 40 ciliate cells were examined for each sample. A time-zero control was prepared to account for FLB adsorbed to cell surfaces of the protozoa.

Specific ingestion rate $\left(I_{\mathrm{s}}\right.$, bacteria protozoan cell ${ }^{-1}$ $\mathrm{h}^{-1}$ ) of HNF or ciliates was calculated as follows

$$
I_{\mathrm{s}}=\left(G_{\mathrm{f}} \times N_{\mathrm{b}}\right) /\left(P \times N_{\mathrm{f}} \times T\right)
$$

where $G_{f}$ is the number of FLB ingested by protozoa, $N_{\mathrm{b}}$ and $N_{\mathrm{f}}$ are respectively the densities of bacteria (cells $\mathrm{ml}^{-1}$ ) and FLB (particles $\mathrm{ml}^{-1}$ ), $P$ is the number of protozoa examined to determine their ingestion of FLB and $T$ is time (hours). Consumption rate $\left(I_{c}\right.$, bacteria $\mathrm{ml}^{-1} \mathrm{~d}^{-1}$ ) of HNF or ciliates was calculated as

$$
I_{c}=I_{\mathrm{s}} \times N_{\mathrm{p}} \times 24
$$

where $N_{\mathrm{p}}$ is the density of protozoa (cells $\mathrm{ml}^{-1}$ ).

Total consumption rates of bacteria (bacteria $\mathrm{ml}^{-1}$ $\mathrm{d}^{-1}$ ) by protozoa were calculated as the sum of the ingestion rates of HNF and ciliates, and bacterial turnover rates $\left(\% \mathrm{~d}^{-1}\right)$ were estimated by expressing the ingested bacteria as percentages of the corresponding bacterial densities.

\section{RESULTS}

Water temperature at the surface of Furuike Pond gradually increased from $24 \mathrm{March}\left(12.8^{\circ} \mathrm{C}\right)$ to $10 \mathrm{Au}$ gust $\left(28.9^{\circ} \mathrm{C}\right)$ and decreased from 24 August $\left(27.3^{\circ} \mathrm{C}\right)$ to 24 October $\left(20.2^{\circ} \mathrm{C}\right.$ ) (Fig. 2). At the beginning of the study, chlorophyll a concentration (Fig. 2) was high (466 $\mu \mathrm{g} \mathrm{I}^{-1}$ ) due to a bloom of Phormidium mucicola (Cyanophyceae). It decreased rapidly to $96.3 \mu \mathrm{g} \mathrm{l}^{-1}$ on 24 March as the bloom collapsed but increased again from 24 April $\left(145 \mathrm{\mu g} \mathrm{l}^{-1}\right)$ to its maximum on $10 \mathrm{July}$ (367 $\mathrm{\mu g} \mathrm{l}^{-1}$ ) except for a sharp dip on $24 \mathrm{June}(36.6 \mu \mathrm{g}$ $\left.\mathrm{l}^{-1}\right)$. Thereafter, it fluctuated between 236 and $333 \mu \mathrm{g}$ $\mathrm{l}^{-1}$. Dominant phytoplankton species during the study period were the Cyanophyceae Microcystis aeruginosa, $P$. mucicola and Anabaena flos-aquae, the Cryptophyceae Cryptomonas spp., Chlorophyceae, Acanthosphaera spp., Scenedesmus spp. and Bacillariophyceae, Synedra spp. M. aeruginosa was quantitatively dominant during most of the study period.

Bacterial densities (Fig. 3A) increased from 24 March $\left(2.0 \times 10^{7}\right.$ cells $\left.\mathrm{ml}^{-1}\right)$ to 24 April $\left(4.6 \times 10^{7}\right.$ cells $\left.\mathrm{ml}^{-1}\right)$, decreased sharply to 9 May $\left(1.3 \times 10^{7}\right.$ cells $\left.\mathrm{ml}^{-1}\right)$ then gradually increased to 24 September $\left(4.9 \times 10^{7}\right.$ cells $\mathrm{ml}^{-1}$ ), with minor fluctuations, before decreasing again.

Heterotrophic nanoflagellates (HNF) showed a sharp peak $\left(1.4 \times 10^{5}\right.$ cells $\left.\mathrm{ml}^{-1}\right)$ between 10 March and 10 April (Fig. 3B) and, although their density was again relatively high on 9 May $\left(7.8 \times 10^{4}\right.$ cells $\left.\mathrm{ml}^{-1}\right)$ from then onwards it tended to decrease, reaching $2.4 \times 10^{3}$ cells $\mathrm{ml}^{-1}$ on 10 August. There was again a slight increase from 24 August $\left(5.1 \times 10^{3}\right.$ cells $\left.\mathrm{ml}^{-1}\right)$ to 24 September $\left(2.1 \times 10^{4}\right.$ cells $\left.\mathrm{ml}^{-1}\right)$ but numbers decreased again from 10 October.

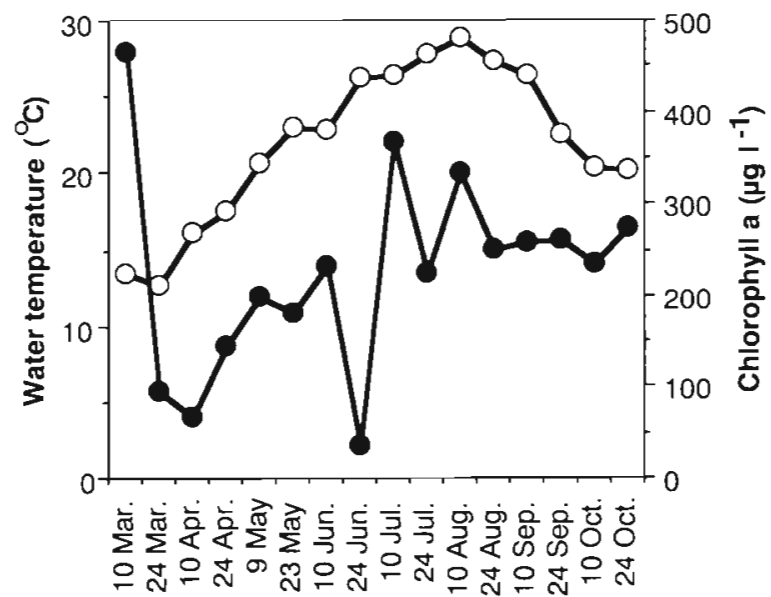

Fig. 2. Seasonal changes in water temperature $(0)$ and chlorophyll a concentration ( $)$ in Furuike Pond during the study period 

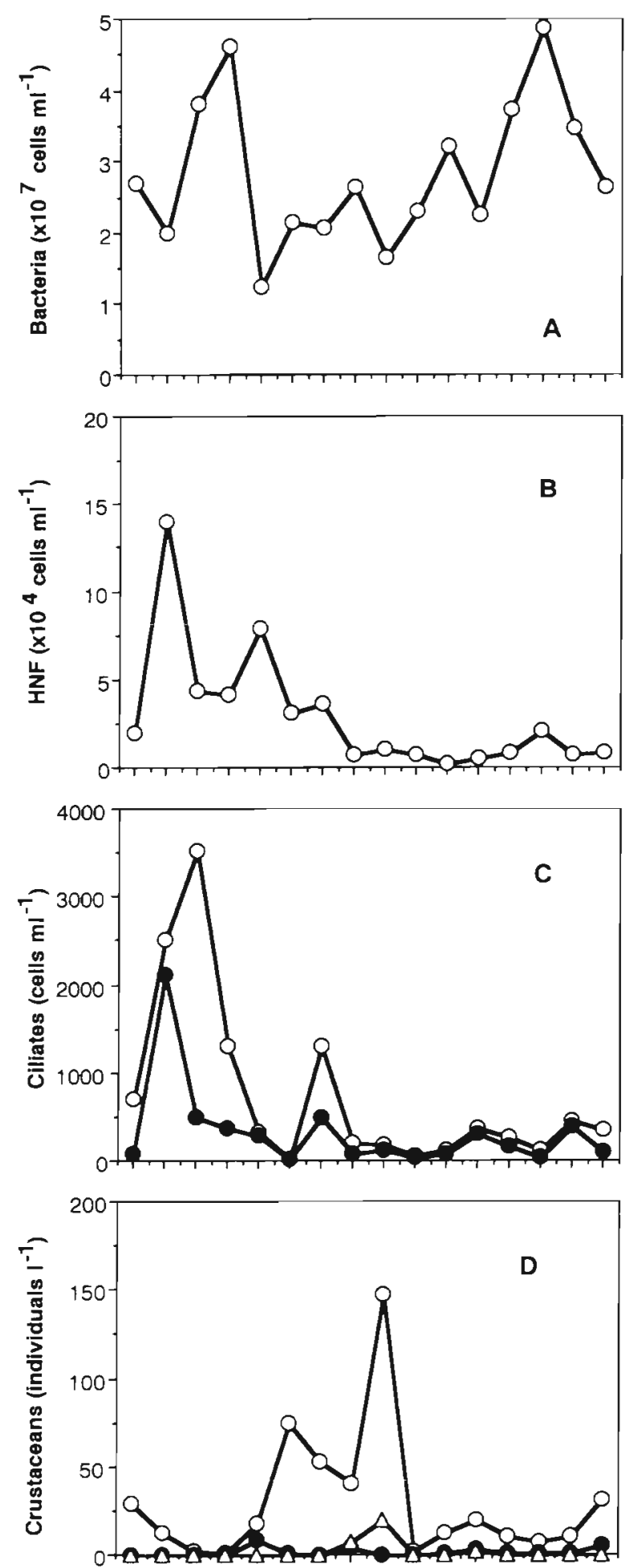

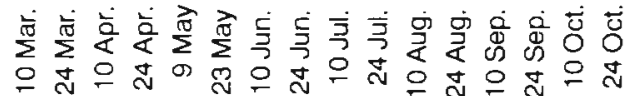

Fig. 3. Seasonal changes in densities of (A) bacteria, (B) heterotrophic nanoflagellates (HNF), (C) total ciliates $(O)$ and bacteria-consuming ciliates ( $)$, (D) cyclopoid copepods (O), Moina sp. (-) and Diaphanosoma sp. ( $\Delta$ ) in Furuike Pond during the study period
Table 1 Dominant genera of ciliates during the study period in Furuike Pond

\begin{tabular}{|ll|}
\hline Date & Ciliate genera \\
\hline $10 \mathrm{Mar}$ & Urotricha, Cyclidium \\
$24 \mathrm{Mar}$ & Cyclidium, Urotricha \\
$10 \mathrm{Apr}$ & Cinetochilum, Halteria \\
$24 \mathrm{Apr}$ & Cinetochilum \\
$9 \mathrm{May}$ & Halteria \\
$23 \mathrm{May}$ & Cyclidium, Urotricha \\
$10 \mathrm{Jun}$ & Cyclidium, Cinetochlum \\
$24 \mathrm{Jun}$ & Cinetochilum, Cyclidium \\
$10 \mathrm{Jul}$ & Cyclidium, Cinetochilum, Urotricha \\
$24 \mathrm{Jul}$ & Cyclidium, Cinetochilum \\
$10 \mathrm{Aug}$ & Cyclidium, Cinetochilum \\
$24 \mathrm{Aug}$ & Cinetochilum, Cyclidium \\
$10 \mathrm{Sep}$ & Cinetochilum, Cyclidium \\
$24 \mathrm{Sep}$ & Cinetochilum, Cyclidium, Strombidium \\
$10 \mathrm{Oct}$ & Cyclidium \\
$24 \mathrm{Oct}$ & Cinetochilum, Cyclidium \\
& \\
\hline
\end{tabular}

During the study period, 5 dominant genera of ciliates were found (Table 1). Judging from the microscopic observation of FLB ingestion by ciliates, we confirmed that Cyclidium spp. and Halteria spp. were consumers of bacteria. Although Cinetochilum sp. is classified as a bacterial consumer in the literature (Patterson \& Hedley 1992, Simek et al. 1995), the food vacuole of this ciliate contained some cyanobacterial cells, and we seldom detected FLB ingestion. Hence, we regarded Cyclidium spp. and Halteria spp. as bacteria consumers, and Cinetochilum sp., Urotricha sp. and Strombidium sp. as algivores in Furuike Pond.

The density of total ciliates (Fig. 3C) increased rapidly from 10 March ( 711 cells ml $^{-1}$ ) to 10 April ( 3500 cells $\mathrm{ml}^{-1}$ ), but declined rapidly to 22 cells $\mathrm{ml}^{-1}$ on 23 May. Apart from a sharp peak on 10 June $(1300$ cells $\mathrm{ml}^{-1}$ ), it fluctuated between 133 and 460 cells ml ${ }^{-1}$ until the end of the study. The pattern of changes in the numbers of bacteria-consuming ciliates was similar to that of total ciliates, except that they declined earlier. Their densities ranged between 11 and 2100 cells ml $^{-1}$ over the season as a whole (Fig. 3C). Small ciliates, bacteria-consumers, Cyclidium spp., and an algivore. Cinetochilum sp. (Table 1), were dominant throughout the study period. In April and May, Halteria spp. and Urotricha spp. were also dominant species, and the latter was detected again on 10 July. Strombidium sp. dominated only on 24 September. Large ciliates such as Monodinium sp. and Strobilidium sp. were sometimes observed, but their densities were low $(<0.2$ cells $\mathrm{ml}^{-1}$ ) throughout the study period.

Cyclopoid copepods, most of which probably belong to the genus Eucyclops, dominated the crustacean zooplankton throughout the study period (Fig. 3D). Individual densities of cyclopoid copepods decreased from 

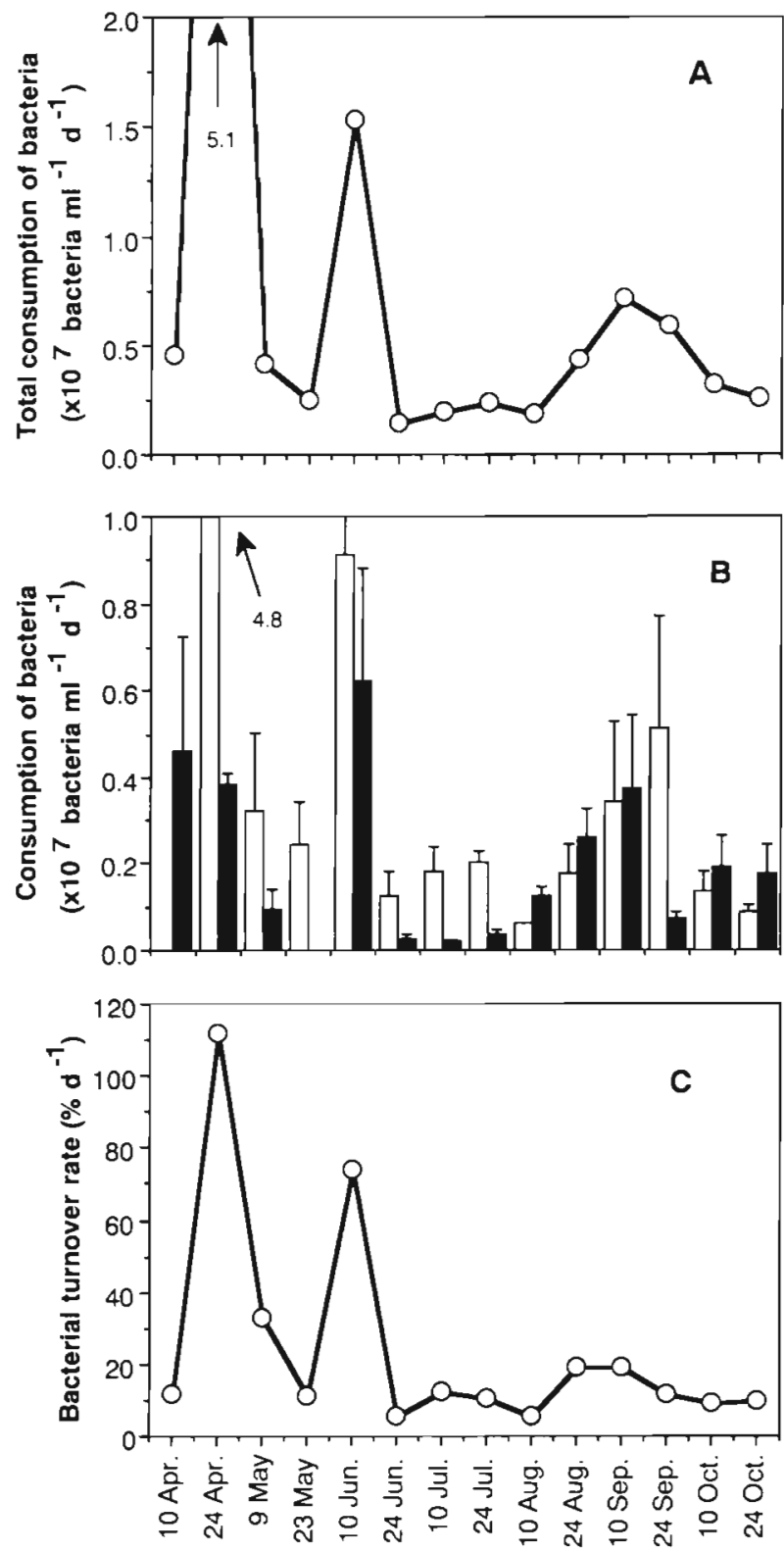

Fig. 4. Seasonal changes in total consumption rate of bacteria by (A) protozoa and (B) heterotrophic nanoflagellates (HNF) (open bars) and ciliates (closed bars) and in (C) bacterial turnover rate in Furuike Pond during the study period. Standard deviations are indicated for consumption rates of HNF and ciliates (B)

the beginning of the study (29 ind. $\left.\mathrm{l}^{-1}\right)$ to 24 April ( 0.83 ind. $\left.\mathrm{l}^{-1}\right)$ and then increased from $9\left(18\right.$ ind. $\left.\mathrm{l}^{-1}\right)$ to 23 May ( 75 ind. $\mathrm{l}^{-1}$ ) before increasing further to the maximum (147 ind. $\mathrm{I}^{-1}$ ) on 10 July after decreasing on 10 and 24 June. Densities of cyclopoid copepods decreased precipitously to 24 July $\left(1.9\right.$ ind. $\left.\mathrm{I}^{-1}\right)$, and there were small fluctuations between 6.9 (24 September) and 32 ind. $\mathrm{l}^{-1}$ (24 October) until the end of the study period. The only cladocerans we found were Dia- phanosoma sp. and Moina sp. Their densities were low throughout the study period (Fig. 3D): $<20$ ind $\mathrm{l}^{-1}$ for Diaphanosoma sp. and $<9$ ind. $\mathrm{l}^{-1}$ for Moina sp. Densities of Diaphanosoma sp. made 2 peaks: one was from 24 June $\left(7.0\right.$ ind $\left.^{-1}\right)$ to 10 July $\left(20\right.$ ind $\left.~^{-1}\right)$, the other on 24 August (1.9 ind. $\mathrm{l}^{-1}$ ). Individual densities of Moina $\mathrm{sp}$. were relatively high when those of cyclopoid copepods were also high from 9 May ( 8.8 ind. $\mathrm{l}^{-1}$ ) to 24 June (4.0 ind. $\mathrm{l}^{-1}$ ). Thereafter, the densities were occasionally high on 24 August ( 3.4 ind. $\mathrm{l}^{-1}$ ) and 24 October (5.3 ind. $\mathrm{l}^{-1}$ ).

To compare seasonal changes in abundance of organisms we used Spearman rank correlation analysis for concentration of chlorophyll $a$ and abundance of bacteria, protozoans and crustaceans. Unfortunately, we could not find any correlations among these parameters.

Total consumption of bacteria by protozoa (the sum of ingestion rates of $\mathrm{HNF}$ and ciliates) (Fig. 4A) fluctuated from 10 April to 24 June between $2.5 \times 10^{6}$ (23 May) and $5.1 \times 10^{7}$ bacteria $\mathrm{ml}^{-1} \mathrm{~d}^{-1}$ (24 April). It decreased to a minimum $\left(1.5 \times 10^{6}\right.$ bacteria $\left.\mathrm{ml}^{-1} \mathrm{~d}^{-1}\right)$ on 24 June, increased until 10 September $\left(7.2 \times 10^{6}\right.$ bacteria $\left.\mathrm{ml}^{-1} \mathrm{~d}^{-1}\right)$ and decreased again from 24 September. On 10 April only ciliates were consuming bacteria, accounting for $100 \%$ to the total (Fig. 4B). From 24 April to 24 July, consumption of bacteria by HNF predominated. On 10 June, the contribution of ciliates $\left(6.2 \times 10^{6}\right.$ bacteria $\mathrm{ml}^{-1} \mathrm{~d}^{-1}$ ) was also important. From 10 August, the ciliates generally dominated $(>50 \%$ ) the total consumption of bacteria until the end of the study, although consumption by HNF was the highest on 24 September.

Table 2. Specific ingestion rates (bacteria protozoan cell ${ }^{-1} \mathrm{~h}^{-1}$ ) of heterotrophic nanaflagellates (HNF) and ciliates in the literature (mean values, ranges or mean $\pm \mathrm{SD}$ ) and the present study (mean $\pm \mathrm{SD}$ )

\begin{tabular}{|c|c|c|c|}
\hline Protozoa & $\begin{array}{l}\text { Specific } \\
\text { ngestion rate }\end{array}$ & $\mathrm{n}$ & Source \\
\hline \multicolumn{4}{|l|}{ HNF } \\
\hline Monas sp. & $3-23$ & & Sanders et al. (1989) \\
\hline Choanoflagellates & $8-42$ & & Sanders et al. (1989) \\
\hline $\begin{array}{l}\text { Spumella-like } \\
\text { chrysomonads }\end{array}$ & $21 \pm 11$ & 102 & Simek et al. (1997) \\
\hline Bodonids & $36 \pm 17$ & 50 & Simek et al. (1997) \\
\hline Choanoflagellates & $53 \pm 19$ & 50 & Simek et al. (1997) \\
\hline Mixed HNF & $12 \pm 12$ & 4284 & This study \\
\hline \multicolumn{4}{|l|}{ Ciliates } \\
\hline $\begin{array}{l}\text { Halteria } \\
\text { grandinella }\end{array}$ & $67-1276$ & & Sanders et al. (1989) \\
\hline $\begin{array}{l}\text { Halteria } \\
\text { grandinella }\end{array}$ & 1580 & 118 & Simek et al. (1995) \\
\hline Cyclidium sp. & 470 & 30 & Simek et al. (1995) \\
\hline Halteria spp. & $159 \pm 78$ & 37 & This study \\
\hline Cyclidium spp. & $321 \pm 248$ & 212 & This study \\
\hline
\end{tabular}




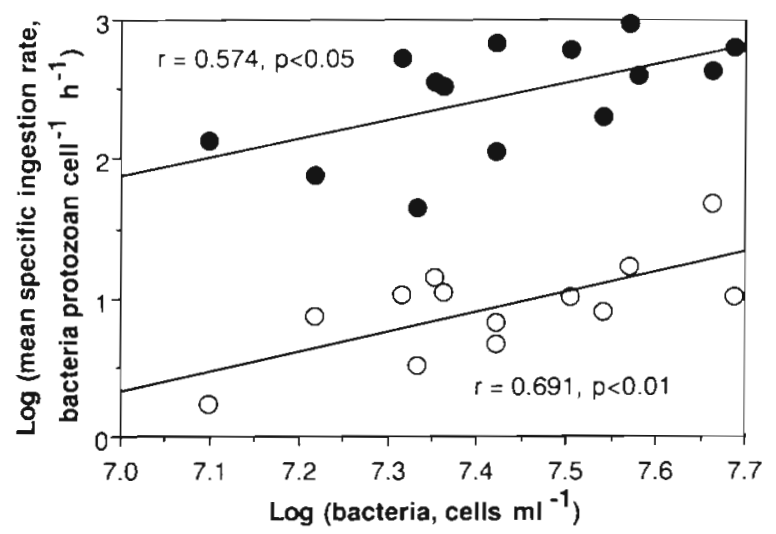

Fig. 5. Logarithmic relationships between mean specific ingestion rates of heterotrophic nanoflagellates (HNF) (O) and bacteria-consuming ciliates (1) and bacterial cell density

The pattern of bacterial turnover rates $\left(\% \mathrm{~d}^{-1}\right)$ (Fig. 4C) was similar to that of consumption of bacteria by protozoa (Fig. 4A). In most cases, turnover rates were less than $30 \% \mathrm{~d}^{-1}$, and very high rates were detected only on 24 April $\left(112 \% \mathrm{~d}^{-1}\right)$ and 10 June $\left(74 \% \mathrm{~d}^{-1}\right)$.

The specific ingestion rate of HNF in the present study was $12 \pm 12$ bacteria flagellate ${ }^{-1} \mathrm{~h}^{-1}$, that of $\mathrm{Hal}$ teria spp. was $159 \pm 78$ bacteria ciliate ${ }^{-1} \mathrm{~h}^{-1}$ and that of Cyclidium spp. was $321 \pm 248$ bacteria ciliate ${ }^{-1} \mathrm{~h}^{-1}$ (Table 2). There were significant logarithmic relationships between densities of bacteria and mean specific ingestion rates (bacteria flagellate ${ }^{-1} \mathrm{~h}^{-1}$ ) of HNF $(\mathrm{p}<$ 0.01 ), and between densities of bacteria and mean specific ingestion rates (bacteria ciliate ${ }^{-1} \mathrm{~h}^{-1}$ ) of bacteriaconsuming ciliates $(p<0.05)$ (Fig. 5).

\section{DISCUSSION}

Furuike Pond has some features of hypereutrophic lakes as reviewed by Sommaruga \& Robarts (1997): for example, high phytoplankton biomass, dominance of cyanobacteria, sudden collapses of algal blooms and low abundance of macrozooplankton. Also, the relationship between the average bacterial abundance $\left(2.8 \times 10^{7} \mathrm{cells} \mathrm{ml}^{-1}\right)$ and the average chlorophyll concentration $\left(227 \mathrm{\mu g} \mathrm{l}^{-1}\right)$ in the present study agrees well with that given by Sommaruga \& Robarts (1997). Thus, it is likely that the biological features of Furuike Pond are typical for hypereutrophic lakes. Although we detected extremely high densities of ciliates in the present study (Fig. 3C), such high abundances of ciliates are probably found in other hypereutrophic lakes. Unfortunately, we still have limited information about microbiology and ecology in hypereutrophic environments.
The predominant phytoplankton during most of the study period was Microcystis aeruginosa. It is well known that $M$. aeruginosa is inedible for many metazoan zooplankton because of its large colony size and toxin production (Fulton \& Pearl 1987). Hence, one may think that the biomass of bacteria, heterotrophic nanoflagellates (HNF) and ciliates is important as food for metazoan zooplankton during the period of Microcystis dominance. Indeed, high abundances of bacteria, HNF and ciliates were detected in the present study (Fig. 3). The few zooplankters, however, can subsist on microbial food sources (Kamjunke et al. 1997), and copepods are inefficient predators for bacteria (Nagata \& Okamoto 1988 , Sanders et al. 1989) and protozoa (Jürgens et al. 1996) Thus, although the microbial loop in Furuike Pond is substantial, the food linkage between microbial and classical food chains is probably small.

We do not have any evidence of toxin production by Microcystis aeruginosa. However, densities of HNF and ciliates decreased (Fig. 3) as concentrations of chlorophyll increased (Fig. 2). Effects of algal toxins on growth of HNF have recently been studied (Christoffersen 1996, Pearl \& Pinckney 1996). Thus, the decrease in protozoan densities may have been due to Microcystis toxin. Šimek \& Straskrabova (1992) and Simek et al. (1998) noted that the genus Cyclidium became dominant when the abundance of large or floc-forming phytoplankters was high in a mesoeutrophic reservoir and a dystrophic lake, respectively. However, we could not find any coupled oscillations between abundance of Cyclidium spp. and concentration of chlorophyll, and between the abundance of Cyclidium and $M$. aeruginosa (data not shown). Since chlorophyll level in the present study (mean $227 \mu^{-1} \mathrm{~g}^{-1}$ ) is much higher than that of the 2 previous studies $\left(<40 \mu \mathrm{g} \mathrm{I}^{-1}\right)$, it is likely that toxic effect of M. aeruginosa in the present study was more serious than that of the previous studies. By contrast, densities of cyclopoid copepods increased, following the decrease in protozoan density (Fig. 3). Possible planktonic food for the copepods is phytoplankton other than Microcystis, HNF, ciliates and rotifers, and we have not yet seen which organism is important for growth of copepods.

Unfortunately, we could not find clear trophic interactions among bacteria, HNF and ciliates, and between microbial and classical food chains. There was a gradual increase in bacterial density from 23 May to 24 September when densities of HNF and ciliates were relatively low (Fig. 3). This may be another type of trophic interaction: bacterial density increases as that of protozoa decreases due to Microcystis toxin.

The mean specific ingestion rates of HNF, Halteria spp. and Cyclidium spp. in Furuike Pond (Table 2) overlapped those of previous studies (Sanders et al. 1989, Simek et al. 1995, 1997). Thus, consumption of 
bacteria in the present study is comparable with previous measurement of bacterivory using the FLB method. No ingestion of FLB by HNF was detected on 10 April (Fig. 4C). It has been reported that some HNF do not ingest FLB (Landry et al. 1991), that some even prefer fluorescently labeled prey instead of unlabelled prey (Mischke 1994) and that some HNF species show a variable selectivity depending on their nutritional state (Jürgens \& DeMott 1995). Thus, consumption rate on bacteria by HNF can be underestimated by the FLB method. The early dramatic decrease in chlorophyll a concentration was due to the collapse of the Phormidium mucicola bloom (Fig. 2) and, since most of this alga was single-celled with a cell size of 1 to $5 \mu \mathrm{m}$, which was appropriate for grazing by HNF and ciliates, it is likely that the decrease was caused by heavy grazing. The lack of ingestion of FLB on 10 April may have been because the HNF were preferentially grazing the alga at that time. Unfortunately, we did not check whether HNF contained the alga on that date.

In the present study, there are not any data showing that Cinetochilum sp. does not ingest bacteria, though we regarded the ciliate as an algivore. Bacteria, if they form flocs or clumps, are probably important food for the ciliates, but the ciliate cannot sieve dispersed bacteria. This is the possible reason for rare FLB ingestion by Cinetochilum sp.

Consumption of bacteria by HNF dominated from 10 April to 10 June, while that by ciliates was also important from 10 August to 24 October (Fig. 4C). Thus, not only HNF but also ciliates are important bacteria consumers in Furuike Pond. There is partitioning of bacterial food between HNF, ciliates and cladocerans (Sanders et al. 1989, Simek et al. 1990, 1998, Simek \& Straskrabova 1992, Nakano et al. 1998), and consumption of bacteria by ciliates occasionally becomes the largest in total consumption of bacteria in mesoeutrophic (Šimek et al. 1990, Simek \& Straskrabova 1992) and dystrophic (Śmek et al. 1998) lakes. However, we still have limited information about bacterial consumption by protozoa in hypereutrophic lakes.

The consumption rates of bacteria (Fig. 4A) were occasionally very high, and the maximum bacterial turnover rate was estimated as $112 \% \mathrm{~d}^{-1}$ (Fig. 4C). Sanders et al. (1992) reported that higher bacterial production was detected in more eutrophicated waters while Jürgens \& Stolpe (1995) reported that, in a eutrophic lake, more than $80 \%$ of bacterial production was removed per day by HNF alone. Thus, the high bacterial turnover rates in the present study probably mean high bacterial production. The bacterial turnover rates, however, are minimum estimates because they are based only on consumption of bacteria by protozoa. Viral infection also contributes significantly to bacterial mortality (Fuhrman \& Noble 1995, Weinbauer \& Höfle 1998).
Using data from various aquatic environments, Vaque et al. (1994) have reported that specific ingestion rate of HNF positively correlated with temperature and bacterial abundance. We found a significant relationship between density of bacteria and specific ingestion rate of HNF in Furuike Pond (Fig. 5). The relationship means tight food linkage between bacteria and HNF. A relationship between density of bacteria and specific ingestion rate of ciliates was also significant (Fig. 5). This, however, must be evaluated with some caution, because there are various functional group in ciliates due to their different feeding modes.

In the present study, we found substantial food linkage between bacteria and protozoans in Furuike Pond: high bacterial turnover rates due to protozoan grazing and significant relationships between abundance of bacteria and specific ingestion rate of protozoa. However, trophic interactions between HNF and ciliates, and between microbial and classical food chains, are still unclear. Although the food linkage between the microbial loop and metazoan zooplankton in the pond is probably less important, we need to quantify predation rates of ciliates on HNF and those of rotifers and cyclopoid copepods on both HNF and ciliates to evaluate the linkage. Further, simultaneous measurements of production and loss within both the microbial loop and the classical food chain will be required to elucidate material cycling in order to verify the role of the microbial loop in an aquatic ecosystem.

Acknowledgements. We are grateful to A. Ohshima, A. Yagi, $\mathrm{K}$. Okamoto, M. Ueki and other members of the Ecosystem Conservation Laboratory, Ehime University, for their advice, discussions and encouragement throughout the study. We also thank Dr Y Watanabe for his donation of a minicell-producing mutant of Escherichia coli. This study forms a part of Guest Scientist Activities, Center for Ecological Research, Kyoto University. This study was partly supported by a Japanese Ministry of Education, Science and Culture, Grant-in-Aid for Creative Basic Research (09NP1501), 'An interactive study on biodiversity conservation under global change and bioinventory management system', by a grant-in-aid from the Ministry of Education, Science, Sports and Culture, Japan (No. 08308031) and by the Showa Shell Sekiyu Foundation for Promotion of Environmental Research.

\section{LITERATURE CITED}

Berninger UG, Wickham SA, Finlay BJ (1993) Trophic coupling within the microbial food web: a study with fine temporal resolution in a eutrophic freshwater ecosystem. Freshwater Biol 30:419-432

Bloem J, Bär-Gilissen MJB (1989) Bacterial activity and protozoan grazing potential in a stratified lake. Limnol Oceanogr 34:297-309

Burns CW, Gilbert JJ (1993) Predation on ciliates by freshwater calanoid copepods: rates of predation and relative vulnerabilities of prey. Freshwater Biol 30:377-393 
Caron DA (1983) Technique for enumeration of heterotrophic and phototrophic nanoplankton, using epifluorescence microscopy, and comparison with other procedures. Appl Environ Microbiol 46:491-498

Carrick HJ, Fahnenstiel GL, Stoermer EF, Wetzel RG (1991) The importance of zooplankton-protozoan trophic couplings in Lake Michigan. Limnol Oceanogr 36: $1335-1345$

Christen AA, Paul ML, Manzara T, Lurquin PF (1983) Rapid isolation of Escherichia coli minicells by glass-fiber filtration: study of plasmid-coded polypeptides. Gene 23: 195-198

Christoffersen K (1996) The effect of microcystin on growth of single species and on mixed natural populations of heterotrophic nanoflagellates. Nat Toxins 4:215-220

Dobberfuhl DR, Miler R, Elser JJ (1997) Effects of a cyclopoid copepod (Diacyclops thomasi) on phytoplankton and the microbial loop. Aquat Microb Ecol 12:29-37

Dolan JR, Gallegos CL (1991) Trophic coupling of rotifers, microflagellates, and bacteria during fall months in the Rhode River Estuary. Mar Ecol Prog Ser 77:147-156

Fuhrman JA, Noble RT (1995) Viruses and protists cause similar bacterial mortality in coastal seawater. Limnol Oceanogr 40:1236-1242

Fulton RS, Pearl HW (1987) Toxic and inhibitory effects of the blue-green alga Microcystis aeruginosa on herbivorous zooplankton. J Plankton Res 9:837-855

Jürgens K (1994) Impact of Daphnia on planktonic microbial food webs - a review. Mar Microb Food Webs 8:295-324

Jürgens K, DeMott WR (1995) Behavioral flexibility in prey selection by bacterivorous nanoflagellates. Limnol Oceanogr 40:1503-1507

Jürgens K, Stolpe G (1995) Seasonal dynamics of crustacean zooplankton, heterotrophic nanoflagellates and bacteria in a shallow, eutrophic lake. Freshwater Biol 33: $27-38$

Jürgens $K$, Wickham SA, Rothhaupt KO, Santer B (1996) Feeding rates of macro- and microzooplankton on heterotrophic nanoflagellates. Limnol Oceanogr 41:1833-1839

Kamjunke N, Böing W, Voigt H (1997) Bacterial and primary production under hypertrophic conditions. Aquat Microb Ecol 13:29-35

Landry MR, Lehner-Fournier JM, Sundstrom JA, Fagerness VL, Selph KE (1991) Discrimination between living and heatkilled prey by a marine zooflagellate, Paraphysomonas vestita (Stokes). J Exp Mar Biol Ecol 146:139-151

McManus GB, Okubo (1991) On the use of surrogate food particles to measure protistan ingestion. Limnol Oceanogr 36:613-617

Mischke U (1994) Influence of food quality and quantity on ingestion and growth rates of three omnivorous heterotrophic flagellates. Mar Microb Food Webs 8:125-143

Mizuno T, Takahashi E (eds) (1991) An illustrated guide to freshwater zooplankton in Japan. Tokai University Publishers, Tokyo (in Japanese)

Nagata T (1986) Carbon and nitrogen content of natural planktonic bacteria. Appl Environ Microbiol 52:28-32

Nagata T (1988) The microflagellate-picoplankton food linkage in the water column of Lake Biwa. Limnol Oceanogr 33:504-517

Nagata T, Okamoto K (1988) Filtering rates on natural bacteria by Daphnia longispina and Eodiaptomus japonicus in Lake Biwa. J Plankton Res 10:835-850

Nakano S (1994) Carbon:nitrogen:phosphorus ratios and nutrient regeneration of a heterotrophic flagellate fed on bacteria with different elemental ratios. Arch Hydrobiol 129:257-271
Nakano S, Koitabashi T, Ueda T (1998) Seasonal changes in abundance of heterotrophic nanoflagellates and their consumption of bacteria in Lake Biwa with special reference to trophic interactions with Daphnia. Arch Hydrobiol 142: $21-34$

Pace ML, Funke E (1991) Regulation of planktonic microbial communities by nutrients and herbivores. Ecology 72 : 904-914

Patterson DJ, Hedley S (1992) Free-living freshwater protozoa. A colour guide. Wolfe Publishing Ltd, London

Pearl HW, Pinckney JL (1996) A mini-review of microbial consortia: their roles in aquatic production and biogeochemical cycling. Microb Ecol 31:225-247

Porter KG, Feig YS (1980) The use of DAPI for identifying and counting aquatic microflora. Limnol Oceanogr 25: 943-948

Rami M, Porath D (1980) Chlorophyll determination in intact tissues using N, N-dimethylformamide. Plant Physiol 65: $478-479$

Sanders RW, Porter KG (1990) Bacterivorous flagellates as food resources for the freshwater crustacean zooplankter Daphnia ambigua. Limnol Oceanogr 35:188-191

Sanders RW, Porter KG, Bennet SJ, DeBiase AE (1989) Seasonal patterns of bacterivory by flagellates, ciliates, rotifers, and cladocerans in a freshwater planktonic community. Limnol Oceanogr 34:673-687

Sanders RW, Caron DA, Berninger UG (1992) Relationships between bacteria and heterotrophic nanoplankton in marine and fresh waters: an inter-ecosystem comparison. Mar Ecol Prog Ser 86:1-14

Sanders RW, Leeper DA, King CH, Porter KG (1994) Grazing by rotifers and crustacean zooplankton on nanoplanktonic protists. Hydrobiologia 288:167-181

Sherr BF, Sherr EB, Fallon RD (1987) Use of monodispersed, fluorescently labeled bacteria to estimate in situ protozoan bacterivory. Appl Environ Microbiol 53:958-965

Simek K, Straskrabova V (1992) Bacterioplankton production and protozoan bacterivory in a mesotrophic reservoir. J Plankton Res 14:773-787

Simek K, Macek M, Seda J, Vyhnalek (1990) Possible food chain relationships between bacterioplankton, protozoans and cladocerans in a reservoir. Int Rev Ges Hydrobiol 75 : $583-596$

Simek K, Bobkova KJ, Macek M, Nedoma J (1995) Ciliate grazing on picoplankton in a eutrophic reservoir during the summer phytoplankton maximum: a study at the species and community level. Limnol Oceanogr 40: $1077-1090$

Simek K, Hartman P, Nedoma J, Pernthaler J, Springmann D, Vrba J, Psenner R (1997) Community structure, picoplankton grazing and zooplankton control of heterotrophic nanoflargellates in a eutrophic reservoir during the summer phytoplankton maximum. Aquat Microb Ecol 12: 49-63

Simek K, Babenzien D, Bittl T, Koschel R, Macek M, Nedoma J, Vrba J (1998) Microbial food webs in an artificially divided acidic bog lake. Int Rev Hydrobiol 83:3-18

Sommaruga R, Robarts RD (1997) The significance of autotrophic and heterotrophic picoplankton in hypertrophic ecosystems. FEMS Microbiol Ecol 24:187-200

Stensdotter-Blomberg U (1998) Factors controlling pelagic populations of ciliates and heliozoans-late summer investigations in an acidic lake before and after liming. J Plankton Res 20:423-442

Stoecker DK, Capuzzo JM (1990) Predation on protozoa: its importance to zooplankton. J Plankton Res 12:891-908

Tezuka Y (1974) An experimental study on the food chain 
among bacteria, Paramecium and Daphnia. Int Rev Ges Hydrobiol 59:31-37

Vadstein O, Jensen A, Olsen Y, Reinertsen H (1988) Growth and phosphorus status of limnetic phytoplankton and bacteria. Limnol Oceanogr 33:489-503

Vaque D, Gasol JM, Marrase C (1994) Grazing rates on bac-

Editorial responsibility: Karel Simek,

Ceské Budèjovice, Czech Republic teria: the significance of methodology and ecological factors. Mar Ecol Prog Ser 109:263-274

Weinbauer MG, Höfle MG (1998) Significance of viral lysis and flagellate grazing as factors controlling bacterioplankton production in a eutrophic lake. Appl Environ Microbiol 64:431-438

Submitted: March 23, 1998; Accepted: June 26, 1998 Proofs received from author(s): November 13, 1998 